\title{
LAS MARCAS DE LAS RESISTENCIAS
}

Dra. Paola Bonavitta

El Dossier "Estudios Feministas y Educación: retos, avances y desafíos en el contexto actual" ha sido un hermoso trabajo repleto de compromiso, proposiciones y apuestas. Repensar la educación desde una perspectiva feminista no sólo se vuelve una reflexión necesaria sino que también es urgente. América latina está atravesando un contexto muy difícil. Los gobiernos neoliberales han invadido la región y los fascismos aparecen con fuerza y sin descaro alguno. El odio a las diferencias, a las disidencias sexuales, a las y los pobres, campesinos, negras y negros e indígenas crece con intensidad en los diferentes países del territorio de Abya Yala. El feminismo parece ser la única salida a este contexto, la posibilidad viable de pensar y crear un mundo diferente con alternativas serias que promuevan la equidad.

Con este Dossier pretendemos provocar la reflexión sobre la situación de la educación - entendida en sentido amplio- en el marco de los cambios sociales, políticos, culturales y económicos de nuestros territorios del Sur, a partir de la diversidad de posiciones que ocupamos las y los sujetos, de acuerdo a intersecciones como la clase, el género, la etnia, la religiosidad, entre otras, que atraviesan las experiencias de las personas y nuestras propias vivencias cotidianas. Es por ello que podrán encontrar trabajos que reflexionan tanto en la dimensión micro como en la macro social, con el horizonte puesto en repensar, desnaturalizar, reflexionar y rebelarnos ante un orden social sexista, racista, clasista, epistemicida y violento.

Desde este Sur marginal y excluido del que nos habla Boaventura do Sousa Santos, proponemos pensar alternativas feministas. El feminismo, como proyecto emancipador, nos permite eliminar opresiones, odios, racismos, clasismos y sexismos y es por ello que sostenemos que es la única alternativa válida para pensar en un mundo mejor. Y, su vinculación con la educación, es la clave para un cambio real y radical. Educar de nuevas maneras posibles, concretar experiencias superadoras que apuesten a la integración real, a la visibilización y a la eliminación de estructuras opresivas. Abandonar los patrones positivistas de enseñanza que terminan legitimando exclusiones y reproduciendo violencias simbólicas, sosteniendo la falacia de la neutralidad valorativa y promoviendo un individualismo descarnado.

Si se trata de disputar hegemonías, el feminismo es la apuesta clave. Día tras día, en el mundo entero, los cuerpos de las mujeres y de las diversidades son castigados, 
objetualizados, excluidos, violados, censurados, abusados, acosados, masacrados, asesinados. Son cuerpos que no les pertenecen a sus dueñas. Se expropian en nombre del patriarcado y de su socio incondicional: el sistema capitalista. La tríada se completa con el colonialismo que incorpora, además, intersecciones de raza y de etnia. El feminismo incide en todos los planos de la vida y pretende una reforma total y real de las relaciones sociales tales y como están dadas en la actualidad. La crítica es permanente y estructural a un sistema injusto y violento.

Frente a esto, la educación aparece como necesaria, permanente y feminista. Si pensamos en lo institucional, las escuelas nos siguen presentando una mirada androcéntrica. Las mujeres prácticamente no existen en la educación ni en la historia: nos han borrado. En la educación comprendida en un sentido amplio, sucede lo mismo. Las voces de mujeres y de disidencias sexuales no se oyen, no tienen poder. Basta con ver quiénes son los dueños del mundo, en quiénes se concentra el dinero, quiénes reúnen el poder: son varones, son blancos, burgueses y heterosexuales. Entonces, ¿cómo pensar en una real democracia si las mujeres no participamos? ¿Cómo nos pensamos integradas equitativamente si no pertenecemos a los espacios donde se diseñan caminos, rutas, proyectos de cualquier tipo? Se supone que la educación nos hace libres. Pero, ¿cómo somos libres cuando, ya educadas, salimos al mundo y no encontramos espacios representativos en él?

La teoría feminista supone recuperar la experiencia y la subjetividad como categorías desde donde construir conocimiento, asumiendo, claro está, que el conocimiento es parcial y situado. Eso pone en jaque al positivismo dominante y nos invita a pensar en nuevas posibilidades de hacer ciencia y de educar. Los posicionamientos que nos atraviesan deben visibilizarse y cuestionarse, para evitar cualquier tipo de naturalización. Es por ello que introducir la perspectiva feminista en espacios educativos, científicos y académicos, no sólo implica una gran transformación en los programas de las asignaturas, en los diseños curriculares institucionales, en las líneas de investigación y en las formas de enseñanza-aprendizaje, sino que también supone el cuestionamiento de las formas de conocer, de acreditar los saberes e, incluso, el repensar la idea misma de "Universidad" como el lugar del conocimiento universal, moderno, occidental, científico y objetivo. Para que el patriarcado cruja por completo y se desarme, debemos aniquilar a las instituciones que lo sostienen, y, en este marco, la Universidad está siendo cómplice de los saberes colonizadores y patriarcales. Las mujeres seguimos en situación de desigualdad y la Universidad y la institución Ciencia 
Moderna deberían usar sus herramientas para revertir esta situación.

Considerando esto, nuestro aporte en este Dossier ha sido incluir artículos provenientes de múltiples disciplinas, como una apuesta a trascender la ortodoxia disciplinar y salirnos de los límites del canon académico. Asimismo, incluimos una presencia fuerte de imágenes pues consideramos que son arte y movimiento, y sin prácticas artísticas no podemos reinventarnos ni transformar nuestras sujeciones. Además, cuenta con la presencia de invitadas feministas muy reconocidas y de amplia trayectoria que han entendido la urgencia de estos tiempos y han reforzado su compromiso social en momentos claves donde las injusticias se incrementan y generosamente han escrito en este espacio.

El actual contexto neoliberal que impulsa brutales achicamentos de los Estados de la región, así como empobrecimientos, desigualdades sociales, explotación de recursos naturales y humanos, odios por razones de clase-género-raza-sexualidad, nos obliga a pensarnos y posicionarnos desde lugares de mayor complejidad. Como académicas, nuestro compromiso es introducirnos en todos los ámbitos de la vida social, considerando los diferentes escenarios, sujetos y problemáticas. Y, como feministas, debemos reforzar las resistencias y las contrahegemonías y sostener la necesidad de refundar las estructuras sociales a nivel macro y micro. No es tarea sencilla, pues diariamente se multiplican los ataques contra las iniciativas y las propuestas feministas, pero es tan necesario como lo ha sido siempre: poner el cuerpo de las mujeres como territorios de resistencias. Y desde allí educar sin pensar sólo en una educación que acumula saberes legitimados, sino educar para la vida. Una vida libre de violencias y de sexismos, una vida en la que nacer mujer o identificarse con una sexualidad disidente no sea causa de muerte, de injusticia, de desventaja.

Pretendemos que este Dossier nos invite a la reflexión sobre la educación actual pero también que contribuya a la acción y a la puesta en práctica de acciones revolucionarias que permitan repensar y reconstruir los mundos de la vida posibles. La educación no es liberadora per se, sino que necesita de nuestras prácticas y posicionamientos políticos, de nuestras acciones emancipadoras y de un fuerte compromiso social, crítico y feminista para que los muchos mundos posibles escapen a las opresiones de cualquier tipo. Y es ello lo que hemos intentado pensar de manera colectiva en este Dossier.

Queremos agradecer a todas las personas que han participado de este espacio de diversas maneras, pues hemos confluido en una creación colectiva plagada de 
reflexiones y utopías, atreviéndonos a soñar con otros espacios, con otras estructuras y con nuevas y emancipadoras presencias y realidades. 